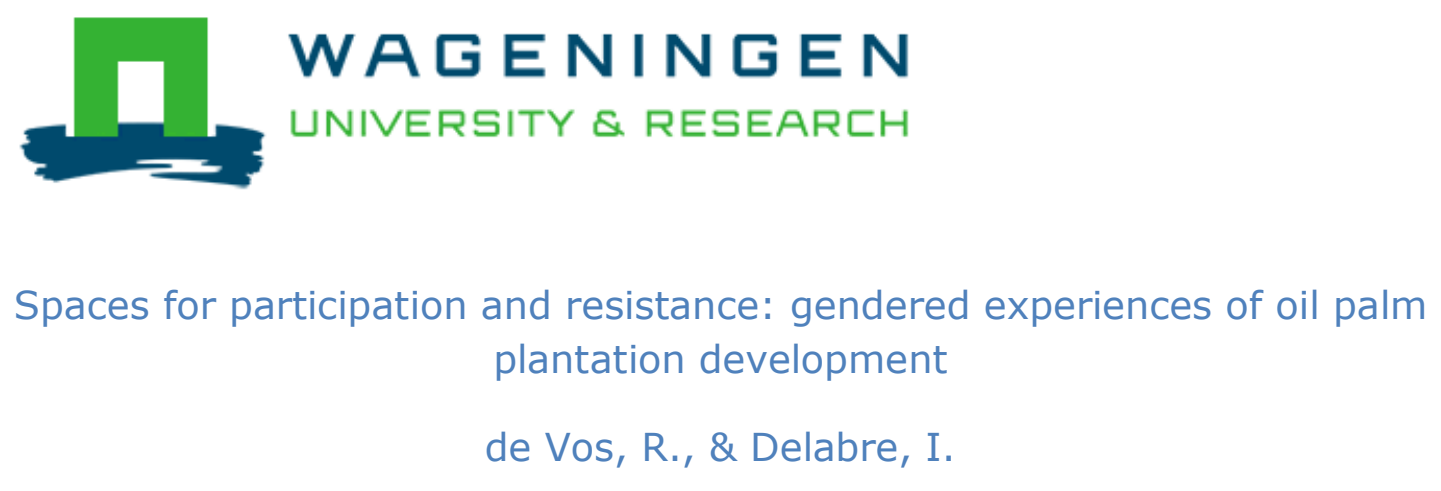

This is a "Post-Print" accepted manuscript, which has been published in "Geoforum"

This version is distributed under a non-commercial no derivatives Creative Commons (c) 1 (1) $\Theta($ (CC-BY-NC-ND) user license, which permits use, distribution, and reproduction in any medium, provided the original work is properly cited and not used for commercial purposes. Further, the restriction applies that if you remix, transform, or build upon the material, you may not distribute the modified material.

Please cite this publication as follows:

de Vos, R., \& Delabre, I. (2018). Spaces for participation and resistance: gendered experiences of oil palm plantation development. Geoforum, 96, 217-226. DOI: 10.1016/j.geoforum.2018.08.011

You can download the published version at:

https://doi.org/10.1016/j.geoforum.2018.08.011 


\title{
Spaces for participation and resistance: gendered experiences of oil palm plantation development
}

Keywords: palm oil; gender; spaces for participation; resistance; micro-politics; positionality

Word count: 9608

\begin{abstract}
:
In this paper, we explore the gendered experiences of, and responses to, socio-economic and environmental change evoked by processes of land acquisition for oil palm plantation development. Drawing upon ethnographic fieldwork in West Kalimantan, Indonesia, we examine the heterogeneous and differentiated nature of women's lived experiences in resisting, accepting and enacting agrarian change. We find that impacts stretch beyond livelihood opportunities, access to land and resources, and labour conditions: plantation development also affects and changes social relations, leading to insecurity and anxiety and new forms of solidarity. Using an analytical framework of 'spaces for participation' we highlight how women are excluded from participation during negotiations and contestations around land acquisition for the development of oil palm plantations. Yet, women also challenge their exclusion by claiming space for participation in different ways, including by engaging in alternative, more subtle forms of resistance that frequently go unnoticed by policies and practices that aim to empower women.
\end{abstract}




\section{INTRODUCTION}

This article explores the gendered experiences of, and responses to processes of land acquisition for the development of large-scale oil palm plantations. Oil palm and other large-scale agribusiness developments can result in significant gendered impacts on local communities, with women being particularly vulnerable to losing access to land, excluded from decision-making processes, and subjected to poor and sometimes dangerous labour conditions. Drawing upon ethnographic fieldwork in West Kalimantan, Indonesia, we explore how women engage with land acquisition processes.. Our study makes visible the practices and spaces for women's participation beyond formal settings of company-community negotiations, from which women are often excluded. We argue that palm oil land deals not only impact women's livelihood opportunities and access to resources, but women's responses shape and transform their socio-economic and political positions. Hence, to better understand gendered impacts, we need to examine women's diverse responses.

This research contributes to an emerging debate about the gendered impacts of oil palm development. After renewed academic interest in the differentiated socio-economic and environmental impacts of agrofuel production on rural populations in the global South (for palm oil, see Castellanos-Navarrete and Jansen, 2015 for Mexico; Feintrenie, 2014 for Central-Africa; McCarthy, 2010 for Indonesia), gradually more attention is being paid to gender dynamics. Empirical studies on gendered impacts by Julia and White (2012), Li (2015), Elmhirst et al. $(2015 ; 2017)$ and Elmhirst and Darmastuti (2015) reveal critical concerns of unequal access to land, poor labour conditions, and the exclusion of women from decision-making regarding land acquisition and plantation development and management. Limited attention to these issues in policy-making can further exacerbate local gender-differentiated impacts related to large-scale land deals (Behrman et al, 2012; Nelson and Lambrou, 2011), risking the further disempowerment of women (Agarwal, 1997), and making them particularly vulnerable to having their "futures precluded" (Li, 2017). In recognition of this concern, there have been efforts to support the participation of women in decision-making by NGOs, companies and other agencies. For example, the Roundtable on Sustainable Palm Oil (RSPO), a multi-stakeholder initiative designed to address environmental and social problems associated with palm oil production through certification, demands that its signatories conduct participatory Social Impact Assessment (SIA), "including women...as appropriate to the situation" (RSPO, 2013: 34). However, the RSPO's requirements and auditing processes have been criticised for their lack of specific attention to gender, or gender is considered a household issue outside the scope of the RSPO (Basnett et al., 2016).

Missing from the current debate is empirical data on the diversity of women's responses to these issues and existing policies may fall short of including women's voices. As gender has become mainstreamed, it is increasingly institutionalised into tools and techniques in development practice, diluting gender's critical and politicised edge, and its transformatory potential as a feminist concept (Elmhirst and Resurreccion, 2008; Leach, 2007). Mainstream policy approaches focus on "how to simply include more women" (Hartcourt, 2016: 168). Elmhirst's discussion of feminist political ecology (2011, this journal) calls for an explicit focus on gender. Moreover, Elmhirst (2011: 7) warns that viewing 'women' as "a homogenous and undifferentiated social category" risks depoliticising gender. Stressing the importance of intersectionality, Haug (2017) demonstrates that gendered impacts of development among the Dayak Benuaq in Kalimantan are highly interwoven with

\footnotetext{
${ }^{1}$ Social Impact Assessment (SIA) incorporates the processes of analysing, monitoring and managing social issues associated with planned interventions (Esteves et al. 2012). Under the RSPO's requirements, SIA should be conducted for both new developments and existing operations, with the participation of affected peoples.
} 
differences in age, class, and education opportunities. People inhabit multiple and fragmented identities, constituted in social relations and networks including gender, class, religion, sexuality, race/ethnicity and post-coloniality (Elmhirst, 2011). Following these notions, we look beyond gendered impacts on livelihoods, to women's responses to and experiences of socio-economic and environmental change related to plantation development, recognizing that contradictions may emerge (O'Shaughnessy and Krogman, 2011), and acknowledging that gender practices are shaped by other social categories, e.g. age, religion, socio-political position; previous experiences, and power differentials that are specific to, and reflective of particular historical and geographical contexts (Lykke 2010). We argue that a focus on gendered experiences reveals forms of inclusion and exclusion crucial in understanding the differentiated impacts of palm oil production. We examine women's positions in interactions with companies and NGOs, and their social relations within communities and households. Our choice to focus on women's experiences of change, rather than socio-economic impacts of oil palm development, is inspired by a notion of agrarian change that focuses on the micro-politics and everyday embodied activities, and everyday forms of resistance or acceptance within processes of transformation (e.g. Kerkvliet, 2009; Nightingale, 2011; Potter, 2008; Scott, 1985). While important research has examined the overt forms of resistance and the ways in which women act as agents of agrarian change through protest against land acquisition for plantation development (Lamb et al., 2017; Morgan, 2017), we argue that a focus on experiences of participation and resistance, including the role of emotions in resource struggles (Sultana, 2011), provides a deeper understanding of opportunities and challenges for women when they are incorporated into the palm oil industry or resist incorporation. We use an analytical framework of 'spaces for participation' to see where and how women engage with processes of oil palm development; or how they might create alternative spaces for participation, enacting forms of resistance or acceptance that often go unnoticed by policy makers, companies and NGOs who aim to empower women. We find that women respond in diverse ways and may exert different forms of agency in alternative spaces.

The paper is outlined as follows. First we provide an overview of literature on the gendered impacts of oil palm. Next, we provide an analytical framework addressing spaces for participation and resistance. We then discuss methodological considerations associated with research on gender, reflecting on positionality and representation issues. In the fourth section, we present empirical accounts of women's experiences and responses to oil palm plantation development and contestations and negotiations relating to this. Our conclusion reflects on spaces for participation in relation to current debates on the inclusion of women in palm oil sustainability standards and policy tools and mechanisms.

\section{GENDERED IMPACTS OF OIL PALM DEVELOPMENT}

The literature reviewed on oil palm and gender reveals three key concerns. First, Julia and White (2012) observe that the arrival of palm oil companies in rural areas leads to major changes in tenurial regimes. Their study on Hibun Dayak in West Kalimantan, found that the Nucleus-Plasma $(\mathrm{NES})^{2}$ plantation system used by oil palm companies in Indonesia leads to an individualisation of communal land tenure systems, because smallholder plasma plots are registered under the head of the household; usually the husband. Julia and White (2012) record cases of women who lost their lands in this way (a problem also observed by Li, 2015). Another consequence of individualisation of

\footnotetext{
${ }^{2}$ A scheme for cooperation between core plantations, owned and managed by companies, and smallholder plots, managed by individual smallholders or cooperatives.
} 
land tenure, reported by Elmhirst et al. (2015: 8), is that “women's relationship with the forest is altered as opportunities such as the production of handicrafts using rattan, bamboo and other forest products have gone". In addition, women lose access to forest products such as edible plants, fruits, firewood, fish, game, and water, potentially jeopardizing food security.

Second, Bissonnette (2012: 127) demonstrates that the division of labour in the palm oil industry is strictly gendered. Women are mostly involved in maintenance such as "spraying pesticides, weeding, clearing bushes and applying fertilizers", whereas men are involved in production such as harvesting (ibid.). While these tasks are regarded as 'lighter' or 'easier' work, women are in contact with harmful pesticides and fertilizers, and safety measures provided by companies are frequently inadequate or lacking. Bissonnette (2012) reports how companies gave women tinned milk to drink to apparently mitigate the harm caused by toxic agrochemicals with which they worked (also observed during fieldwork by one of the authors). Women have less access to contract and casual work, and are denied rights to healthcare, pensions, or other benefits (Li, 2015; 2017). Women depend on good relationships with their supervisors, and if they show resistance, they could be assigned heavier and more hazardous tasks. Moreover, women perform the lowest-paid tasks or are seen as their husbands' 'helpers' and are not paid at all. Li (2015) reports that six female plantation workers in West Kalimantan went on strike for six days to protest wage cuts, but the company threatened them with intimidation. The women's status as casual workers made their efforts to claim their rights ineffective (ibid.). Yet, Li (2017) also demonstrates how women fight back by diverting some of the plantation's wealth by colluding with their supervisors, paying them to look the other way in return for a share. Julia and White (2012) observe a feminisation of agriculture as women continue to work in subsistence farming while also working on plantations, but creating a double burden of labour. Women also try to find additional income by collecting berondol, loose palm fruits on the ground, which companies regard as 'stealing' and women face intimidation from security guards and criminalization (ibid.).

Third, Elhmhirst et al. (2015), Julia and White (2012) and Li (2015) note that women are excluded from participation in decision-making over land transfer deals, smallholder arrangements and working conditions. Elmhirst et al. (2015) report that although there are no formal restrictions to women attending sosialisasi, ${ }^{3}$ husbands usually represent households at meetings. Julia and White (2012) state that women are underrepresented in the Oil Palm Farmer's Union, because membership is based on being registered as a smallholder; usually a man. Also, Li (2015: 15) emphasizes that the system in which men are registered as smallholders means that women cannot become members of cooperatives (plasma holders are usually organized into cooperatives for engagement with companies). She states that the "exclusion of women from co-op membership was a significant failure of the scheme design, a missed opportunity to address a gender injustice by reversing women's marginalization in the public sphere".

\section{SPACES FOR PARTICIPATION}

The literature reviewed provides a comprehensive understanding of the possible negative implications of oil palm plantation development (and operations) for women. Building on this, we look into how women experience and respond to land acquisition preceding plantation development by examining participation of women in organized responses to company practices, such as company-community meetings, internal village meetings and protest actions, as well as indirect ways

\footnotetext{
${ }^{3}$ Sosialisasi (socialisation) is an Indonesian concept for companies to consult and inform communities about projected development initiatives such as plantations.
} 
of engaging with land acquisition processes. This includes everyday practices that are intentionally and unintentionally related to constituting and resisting the transformation of landscapes into plantations.

We dissect the micro-politics and practices that shape "spaces for participation" relating to various stages of plantation development and management, considering their accessibility and how people participate. While processes of "participation" may include meetings, participation can include constructing alternative spaces to exert agency (e.g. as resistance), outside more organized spaces. Scott (1985) and Kerkvliet (2009) have argued that resistance is not always overt and direct: they emphasize the power of everyday forms of resistance as "weapons of the weak" (see Gutmann, 1993 for critique). De Certeau (1984) asserts that "the simple act of walking where one should not" can be a form of resistance by participating in the (re)construction of the landscape, "refuting notions of social and moral order which have been inscribed on the landscape" (as cited in Holloway and Hubbard, 2001: 219). Where De Certeau stresses that "resistive appropriations of everyday spaces" (ibid.) should be tactical, stressing intentionality of such actions, Ingold (2000) deploys the concept of "dwelling" to understand how places come into being: people construct places, physically or imaginatively, through their practical engagement with their surroundings. Thus, everyday practices may not directly represent intentional acts of participation or resistance, but importantly, do shape landscapes. This attention to everyday practices as ways of engaging with, participating in or resisting processes of agrarian change, is not meant to dismiss more overt forms of resistance, through which people might risk their lives for change (Gutmann, 1993). Moreover, it should be recognized that everyday practices may reproduce power relations that exclude women from other forms of participation. Building upon this, we understand participation to mean different forms of engagement that influence decision-making processes (Nightingale, 2002.), recognizing that participation is situated in spaces that are constructed through power relations.

Reflecting on our own ways of participating in processes of knowledge construction regarding land acquisition for oil palm development, we noticed how the places where we conducted research - places where decisions were made about how to tell this story, as well as the very nature of the story - where not equally accessible to all. Adding nuance to Lefebvre's claim that "space is a social product... it is not simply 'there', a neutral container waiting to be filled, but is a dynamic, humanly constructed means of control, and hence of domination, of power" (1991: 24), feminist political ecologists have emphasized how attention to everyday spatial practices gives insight into power relations and the production of difference (e.g. Nightingale, 2011). This leads us to examine how the spaces where women engage in land acquisition, resistance and research are constructed through dynamic power relations.

In this regard, Cornwall (2002) and Gaventa (2004) distinguish between closed, invited, and claimed (or created) spaces for participation. "Spaces can be viewed in a material sense" or "as metaphorical spaces", such as networks (Massey 1994, as cited in Tallontire et al., 2014). Many spaces are 'closed,' as a limited group of actors make decisions behind closed doors, without even superficial endeavours to include others (Gaventa, 2006). It has become the focus of local NGOs to 'open' such spaces to ensure greater public involvement, transparency and accountability (ibid.). As efforts are made to widen participation, new 'invited' spaces are created, in which people are invited to participate (Cornwall, 2002). Invited spaces are often controlled by those who provide them, no matter how participatory they seek to be (Cornwall, 2008). According to Gaventa (2006), those who create the space are more likely to have power within it, and those with power in one space do not necessarily have the same power in another. In invited spaces, power may be interpreted as 
something 'given' by the powerful to the powerless (Leal, 2007). This is problematic, because power becomes conditioned by those who 'give' that power (Tandon, 1995: 33). 'Claimed' or 'created' spaces are formed by less powerful actors as alternatives for spaces where they are excluded (Gaventa, 2006). These are 'organic' spaces that emerge from 'sets of common concerns or identifications' and 'may come into being as a result of spaces in which like-minded people join together in common pursuits' (Cornwall, 2002). Soja (1996) refers to 'third spaces' where actors form their own spaces, rejecting and moving outside of hegemonic space. Such spaces include those created by social movements and community associations, as well as less formal places in which people gather to debate, discuss and resist. Spaces that people create for themselves may sometimes be conceived as 'sites of resistance,' where people come together through collective action (Kohn, 2000). 'Sites of resistance' may also be spaces created within 'invited' spaces through resistance to hegemonic norms (ibid.).

However, Kesby (2005) argues that while participatory spaces may intend to facilitate empowerment, relations constituted elsewhere may limit empowered performances within the space. Hence, spaces exist in dynamic relationship to one another, and boundaries are renegotiated, so power gained in one space can be used to enter and affect other spaces (Gaventa, 2006; Cornwall, 2002). Indeed power relations shape the boundaries of all participatory spaces, influence what is possible within them, who may enter, and which interests, identities and discourses are considered legitimate in such spaces (Gaventa, 2006; Tallontire et al., 2014). It is critical to examine who shapes the space, to whom are they accountable and whose interests they serve (Tallontire et al., 2014). Nightingale (2011) illustrates that spaces are also crucially shaped by material practices, with the physical characters of certain spaces working to include and exclude people (see also Li, 2017 on infrastructural violence). Following the notion of spaces for participation as shaped by both material and social practices embedded in power relations, we examine how women participate in different spaces of participation relating to land acquisition.

\section{METHODOLOGY AND METHODS}

\subsection{Methodology}

The idea for this article emerged when the authors shared their experiences of conducting fieldwork in Sambas, West Kalimantan. This article is based on our separate experiences in the field and our joint reflections. We discussed how we could come to understand what happened during land acquisition processes, and the differences in how people experienced these processes, and realised that knowledge and experiences where constructed and enacted in different kinds of spaces. Our experiences of being 'the only female' in meetings about oil palm projects made us aware that the spaces where we conducted research were not equally accessible to all; knowledge produced in these places excluded women's experiences (see Haraway, 2001). Moving into other spaces - going to the backs of homes, where women lived and assembled - - and listening to their stories, inspired us to critically examine spaces for participation in company meetings, and in resistance activities.

Our focus on women's experiences of plantation development and power relations surrounding participatory spaces necessitates careful attention to the representation of women's voices, "who speaks and on behalf of whom and how" (Reed-Danahay, 1997: 3 as cited in Ali, 2015). We explore not only how women are (passively) impacted by oil palm development but rather how they experience and respond to this in different ways. We incorporate our experiences in the field into our description and analysis through a 'reflexive ethnography' approach (Butz and Besio, 2009). We did not merely observe the gendered experiences and responses of 'others'; we also lived and 
enacted these experiences and responses. At times, we directly experienced the restrictions for women to participate in certain spaces. Initially, our network of contacts for conducting fieldwork mainly consisted of men. The somewhat uncomfortable situation of being the only female present was an opportunity to point out gender issues. Our research approaches sometimes contrasted with social norms: our male guides laughed bemusedly when we first requested to speak to women. During a village meeting, a male village leader became somewhat agitated when one of the authors asked permission to talk to women who had gathered in the kitchen. He asked: "Don't you want to hear about our struggle anymore?" Sometimes alternative spaces were created in the research process, for example when we organised focus group discussions or targeted women for interviews.

Although our backgrounds differ from those of informants in multiple ways, at some points we also shared identities with them, such as being young females (see Muhammad et al. 2014). In some cases, the researchers' positions meant greater access to research subjects. For example, being 'foreign' and 'female' in field sites allowed the researchers to move between different spaces and engage with different research participants. The researchers could navigate between: 'male' spaces, as we were seen as 'foreign' (rather than local) women, and 'female' spaces such as the kitchen, or the rice field. Reflexive ethnography helped to identify the different ways in which women responded to the changes induced by oil palm development, outside of 'formal' spaces of negotiation, uncovering alternative spaces where women have (more) agency.

An important consideration was how we could represent informants' voices. We acknowledge that in ethnography especially, researchers should make attempts to avoid merely writing about informants' experiences and write with informants instead (see Sultana, 2007). Although we wrote the article after having returned from the field, during the research we continually reflected on our observations with informants. One of the authors also revisited the field during the process of writing this article to discuss the findings.

\subsection{Methods}

This study draws upon fieldwork conducted during multiple visits to nine predominantly Malay villages in the district of Sambas, West Kalimantan from 2013 to 2016 for seven months in total. Eight villages were situated in two oil palm concessions held by the same agribusiness group, and conflicts had emerged in both concession areas during the process of land acquisition. Due to protest from local inhabitants, who were connected through a regional farmers' movement, one plantation project was eventually cancelled, and another project went ahead only partially. In this article we focus on women's experiences of engaging with the process of land acquisition and preparatory activities for plantation development that happened within the two concession areas. In addition, we discuss experiences from a visit to a village in a third concession area in the same district where a plantation was already established to illustrate gendered experiences in the last phase of plantation development, where women had become plantation labourers. The fieldwork combined ethnographic methods including participant observation, informal and semi-structured interviews, and focus group discussions. Informants included over 90 male and 45 female ethnic Malay villagers, 
of different classes, and ages; ${ }^{4}$ triangulated with five female NGO workers; plantation company staff (total of 11 including five female); auditors (a total of six including one female); and environmental and social impact assessors (a total of six including two female).

In the villages we researched, people had diverse livelihoods, combining cash crops with subsistence farming. Coconut and rubber were important cash crops, sometimes complemented with black pepper and oil palm. Farmers also produce a wide variety of fruits, pulses and corn in rotation with local and high yielding rice varieties. In some villages, logging and wood carving, rattan and weaving handicrafts were also important sources of income. The volatility of the rubber price and population growth had incited considerable labour migration to Malaysia and logging areas in Indonesia. The majority of respondents had family members working in logging companies, on rubber and oil palm plantations, in construction or hospitality and housekeeping (see Mee, 2015). Agricultural activities are mainly performed by women, as young men usually migrate to find jobs.

Growing use of palm oil in food products and biofuel sparked the rapid growth of oil palm plantation projects throughout Kalimantan (McCarthy and Cramb, 2009). According to a district government report, 202,331 hectares of land in Sambas District have been granted to 35 oil palm companies since 2004, and most of these operations are in early stages of licensing, planting and production. The report indicates that many companies are violating licensing procedures by planting without a Plantation Permit, giving rise to diverse responses by rural communities, from open (and sometimes violent) resistance to acquiescence, to acceptance. Since 2008, there have been demonstrations against at least seven different plantation companies in Sambas (DPRD Sambas District, 2013). ${ }^{5}$ Resistance has focused on land clearing without community consultation and consent, failure to deliver promised smallholder plots, and disagreements about compensation for land acquisition. Some people fear that the conversion of agricultural land and forest into monocultures will diminish access to land and resources and livelihood opportunities for rural communities in Sambas. Moreover, some fear the loss of their autonomy as farmers and their dependence on companies for employment. Others see oil palm plantations as a welcome development to provide jobs and socio-economic development.

\section{GENDERED SPACES FOR PARTICIPATION}

We discuss women's experiences of participation in different spaces: formal 'front room' meetings and demonstrations, and women's participation through everyday practices. We consider the forms of participatory spaces these different setting constitute, and women's agency in these spaces, recognising that gendered agency is heterogenous and relates to interrelating social categories within particular settings.

\footnotetext{
${ }^{4}$ Different classes refers to: people who mainly depend on farming and/ or farm labour for their income with 0.5-3 hectares of land, versus people who have a job with the government, in the private sector or in civil society (often in addition to farming) who have more than 3 hectares of land. In addition, we talked to some relatively wealthy families who often had successful trading businesses. People aged above 30 are overrepresented amongst our interviewees, because adults between 18-30 often worked in Malaysia.
}

\footnotetext{
${ }^{5}$ A search in newspaper archives (Tribun Pontianak) demonstrates that people have demonstrated multiple times against
} the same companies. Seven companies are mentioned in the DPRD report. 


\subsection{Participation in 'front rooms'}

Various authorities, including the Indonesian government and the RSPO, have developed standards for 'community participation' in processes of oil palm plantation development and management, with the aim of preventing conflict and social injustices. However, literature emphasizes that company-community interactions are often characterized by a lack of transparency, information asymmetry, unequal power relations and a lack of participation of especially minority groups within communities (e.g. Gillespie, 2011). Where company-community interactions do exist, they constitute "invited" spaces for participation, controlled by companies, often more focussed on informing communities rather than negotiating with communities. Such interactions include sosialisasi and negotiation meetings prior to plantation development, and negotiation and/or interactions after plantation development.

There is growing recognition in development theory and practice that participatory processes should include women's views and interests. Interviews with companies and social impact assessment (SIA) consultants ${ }^{6}$ reveal limitations to participatory processes. According to an SIA consultant interviewed, when arranging meetings with communities, "you have to follow tradition and norms. In South East Asia, you can't just go to the community and organise a meeting, you have to go to the village head, and then the village head needs to help organise this." The SIA consultant stated that while they can demand a 'good mix' of people, village heads have the freedom to invite specific members of communities, which creates risks of elite capture, further disempowering already marginalised people. Consultants and companies interviewed indicated the specific challenge of the adequate participation of women. When asked broadly about any specific challenges in community participation in SIA, a female SIA consultant stated:

"I've had situations where there have only been one or two women in there, even though I've requested and really asked for them to come. Sometimes they've been timid and quiet and don't say anything. But sometimes actually they have the biggest voice, it depends."

Although consultants have a prominent role in the community-company interactions, a male representative of a plantation company, responsible for the implementation of sustainability certification requirements, was concerned about the lack of female consultants in Indonesia:

"It's a bit of a silly issue but I cannot remember seeing too many girls in the Social Impact Assessment teams...l think it's a lot of men doing the assessments, sometimes they talk to women because we request it and we are interested..." While this plantation company manager considered the lack of female consultants to be a "silly issue," in practice, it may significantly influence the extent to which women participate in SIA, because in certain contexts, it may be considered taboo for women to speak with male consultants.

Despite standards stipulating women's participation and efforts by company staff to invite women, 'invited' spaces for participation are often experienced by women as 'closed' spaces. In some cases, women say they had not been invited at all, and in other cases, women say they had attended, but prevailing social norms prevented them from participating. For example, a female villager stated: "I would have wanted to join the meeting with the company but it would have been taboo, not polite for us to go. The company invites men. It seems impossible for us to go. We have never thought about negotiation. We have never thought we would be part of negotiation. We take care of the children, if we disagree, our husbands don't trust us". Another female villager stated that she will attend a meeting if she is invited, but that she attends just to make up the crowd. She

\footnotetext{
${ }^{6}$ In response to the need for technical expertise and the promised neutrality of third parties, companies sometimes outsource community engagement activities to social impact assessment consultants.
} 
added, "I have no confidence to voice my opinion". When a male villager was asked whether women attend meetings, he stated "mostly, men are the decision makers, and women follow. Normally women don't want to go, and if they do go, they keep quiet, or say 'I don't know what I am going to say.'" Another male villager clearly reflected a perception of women's roles as passive in meetings with companies, saying that "women sometimes attend, and sometimes not. The women's role is only to hear a discussion, but not to talk." As Collins (2014) observes, the participation of women cannot be understood by only looking at women's attendance in meetings. Even when women are invited they may be passive participants. In some situations, it may be the case that women are invited to attend meetings, but they do not wish to attend, as shared by one of the female villagers interviewed, who stated "some women didn't want to go, because they do not want to and are busy with their children". Other women had not even considered that they might have a role to play in negotiations with companies, with one of the female villagers stating "We thought we shouldn't have to go as our husbands were going."

These comments demonstrate local cultural perceptions on gender that restrict women's opportunities for participation in processes of oil palm plantation development and management. Although Sambas had the first female district head in West Kalimantan between 2011-2016, when interviewed, two female staff of Gemawan lamented that in many villages in Sambas women are not involved in village politics and governance, because "men and women do not regard women as leaders, and women often lack confidence to participate." Moreover, they experience time constraints as they have to manage their fields and gardens, and take care of their families, so they cannot attend nightly village meetings. According to the (female) director of Gemawan this is related to cultural norms and practices prevailing throughout West Kalimantan, both in Islamic Malay villages as well as Christian Dayak villages, despite differing cultural and religious contexts, as well as differing political, geographical and historical settings, which shape women's lived experiences. Such norms are evident in formal internal village meetings, often held alongside company-community meetings. Such meetings also take place in 'invited' spaces, such as in the village office or the house of a community leader. In our experience, during such meetings men usually occupy the front (room), whereas the women gather at the back or even in the kitchen. Whenever we asked during such meetings why there were no other women, men would usually reply that since it was late at night the women were tired and they attended to children.

The day after such a meeting, one of the authors visited ibu Nisa who lived with her two adult children in the village; her husband was working in Malaysia. Ibu Nisa was an active member of a women's group and she participated in the village school program organized by Lembaga Gemawan to educate women regarding village governance. I shared my experience of being the only woman in last night's meetings and told her the men said that women do not want to come because the meeting is late at night. However, ibu Nisa refuted this, arguing that women would like to attend but cannot unless they are explicitly invited:

"The problem is that meetings are usually held in the village office. We have to enter through the front door... [She demonstrated how she would enter a room full of men: bending down with her arm forward as a sign of polite modesty for passing a row of sitting men she says: 'Assalamualaikum] $]^{7} . . . '$ we feel shy, right? When we are not invited..."Once I was invited to a formal village meeting. However, the chairmen introduced me as the representative of my husband who was in Malaysia. Even though the invitation explicitly had my name on it."

\footnotetext{
${ }^{7}$ Islamic greeting when entering a house
} 
According to ibu Nisa the problem is the way in which women are invited. If invitations are distributed per household, automatically the men will attend: "I need an invitation that is specifically addressed to me, to have courage to attend". Her comments touch upon a crucial aspect of the problem. Although 'women' sometimes are invited, they are not, unlike men, invited as individuals. Men are often invited because they hold a certain position within the community. This means that although it may be understood that 'women' should be involved in meetings, there is a notion that the representation of 'any women will do,' risking this being a tokenistic effort, 'added on' to development processes.

Interventions intended to support women can be experienced in a variety of ways and our research suggests that these have the potential to both empower and marginalise women. In several villages we studied, Lembaga Gemawan, a local NGO, organises female empowerment groups to educate women, with the intention of enabling them to participate in village governance. During monthly gatherings, women discuss issues such as agriculture, healthcare, and village politics. The female NGO staff who organise these gatherings recognised that attending formal village meetings is restricted to women due to cultural norms and because meetings are often difficult to combine with other household and agricultural tasks. Therefore, the women's group meetings take place at the members' houses at lunchtime.

"If we organise the meetings in a member's house, everyone can join in. You don't have to dress formally. You can join on your way back from the garden. If meetings would be in the office, the women would have to dress formally. Now they can come in their house clothes. That is no problem. This way we create enthusiasm" (female staff Lembaga Gemawan).

In one village, a female empowerment group had been active for some years and its members identified numerous benefits from the group, including connectivity with other women and income diversification through making handicrafts to sell. While some women were vocal within the female empowerment group, they were still excluded from expressing their opinions in public spaces. While some women had powerful positions in certain female-only settings, men's voices continued to dominate public spaces. In another village, a member of a women's group said that the men accept the women's groups, but regard it as a space for 'women issues', not for village politics. The women's group constituted a space operating within an existing hierarchical structure, and while it attempts to drive change, in its current form it is not able to engage with or challenge broader power relations operating in society. Women's 'space' therefore reflects the pre-existing power structure despite the new space, and their political power remains separate from 'public space.' Likewise, the RSPO's guidelines for company-community interactions stipulate that companies should organise side meetings for 'minority groups' within communities, such as women, to ensure their participation. However, having side meetings operating in different spaces further strengthens boundaries between different groups within communities, and does not challenge wider societal conditions and norms per se. Nevertheless, separate meetings could be valuable for women to gain confidence in public speaking, which would be necessary when they join with men's groups, to help strengthen women's political voices.

Participatory activities are being promoted as a way in which companies can avoid conflict and gain a social license to operate. However, the account above shows that women experience the 'invited' formal meeting spaces (between communities and companies and meetings within communities) as closed. In many cases women were not (explicitly) invited to meetings. It is men who control the dynamics of these formal participatory spaces and their boundaries. This makes women reluctant to attend, to speak up, and sometimes women do not consider that they have a 
role in formal meetings about plantation development. Even when women attend meetings this does not ensure actual participation. Therefore, standards and policies that require women's attendance to meetings alone do not address the broader, structural issues of inequalities associated with oil palm plantation development. Women interviewed suggest that one way to address this is to target women as a heterogeneous group (of individuals with different backgrounds and positions within the community), to capture more diverse responses, and ensure better representation. It must also be noted that women's access to public spaces is not always so restricted (Colfer, 2011), especially in some parts of Indonesia, for example, in parts of Southern Sulawesi (Colfer et al., 2015), again reflecting context-specific relationships with forms of governance. Even if companies were to improve their strategies for communication with communities, structural power differences remain; dominant social norms define who should attend meetings, who should speak up, and how men and women should behave in public (Agarwal 2001; see also Borras and Franco 2014 for a critique on 'codes of conduct' for land deals).

\subsection{Participation in demonstrations: throwing stones and the fear of violence}

In response to a lack of opportunities to participate in formal settings, villagers in Sambas have organised organise alternative spaces in which they can voice their interests, such as informal village meetings and demonstrations. Such 'claimed' spaces may provide opportunities for participation and resistance outside of spaces controlled by companies or government actors. In this section, we reflect on the experiences of women in two cases of resistance against plantation projects.

Meetings about resistance are often characterised by the same social norms on gender that prevent women from participating. Nevertheless, some women defied these norms and claimed space for participation. Talking about the demonstration, ibu Ani, who describes herself as a woman with a "strong soul", says she always attends important meetings. Ibu Ani, now in her fifties, worked on oil palm plantations in Malaysia when she was younger to pay for the education of her children until she got injured by a scythe. She said that it is much better to cultivate rice and tap rubber, because working on oil palm plantations is too heavy, especially for women who have to carry heavy baskets of palm fruits. When she heard about the land marks placed by an oil palm company, she wanted to attend the meeting:

"Before the demonstration, we gathered at my house. Many women attended. It is about our rights. The rights of our grandchildren. Our land is taken away, our grandchildren's land. The women did not speak; they sat in the back, they were shy. This is a matter for men."

However, going against her father's wishes, she encouraged her friends to attend the demonstration:

"Six women from our neighbourhood participated in the demonstration. And there were many women from other villages. My father did not think I should go. I invited my friends to come: 'come on, let's demonstrate, it is okay'. We wanted to fight, this was the first time. The women would be impacted first. The women were not afraid, if we beat someone, we will not be punished."

Some women said they joined the demonstration, but remained at the back because they were frightened when the demonstration turned violent. Others stood in front and threw stones at the district government's office, shattering all the windows out of anger that the district head did not come to meet the protesters. During a focus group discussion about this demonstration, a woman whispered to one of the authors: 
"Nobody answered the question who threw stones to the district office. Well, I tell you, I did it. The women started. It was hot, it took a long time and we were frustrated."

Although there are restrictions for women to engage in claimed spaces such as village meetings and demonstrations, some women exercise their agency to enter these spaces. This shows that structural gender norms can be flexible and challenged by women.

A second, more violent, demonstration took place at the base camp of the company, and no women participated. The protesters set fire to the base camp and burned it to the ground. When the police arrived, they clashed with the protesters and two police motorcycles were burned. When interviewed about this story, it was remembered as a heroic success, because afterwards the company cancelled the plantation project and left the area. However, we also learned that it was an emotional and frightening time that had a long-lasting negative impact on social relations in the communities. Although women often said that they had supported their husbands' participation in the demonstration, some women also stressed that they hope that demonstrations would not occur again, and that if they did, they hoped their husbands would not participate. Remembering the demonstration, the face of a woman paled as she whispered her story:

"We heard there would be a demonstration at the base camp. We were afraid, I stayed at home. People said they wanted to demonstrate. I felt weak and scared. It cannot be. I did not know who participated. People came to my house, they asked for water. Please help yourself. I was afraid. There was smoke... It went on for a long time. My child asked 'where is my father?' Your father followed the crowd of people. He could die. Mom, said my child, is father not burned? It is alright, your father is brave. Oh dear, it was like the ethnic conflict. There were opponents and supporters. When my husband came home, I was relieved."

The demonstration reminded her of the ethnic conflict that raged in this area more than a decade ago. The account of this woman sheds a different light on the heroic stories about the demonstration. Although the goal of the protesters was accomplished - the company left the area - the violence had an emotional impact on people. Besides fear for the safety of relatives, women also feared a disruption of social relations within the community. One woman explained that she did not want to participate in the demonstration and certainly not in the 'riot' at the base camp, because she knew many people in that village. She would feel ashamed if people were to say at the market that she had started the fires.

The aftermath of the demonstration had a particularly negative impact on women whose husbands were arrested. After the demonstration, the police circled villages throughout the concession area to find the demonstration leaders. Two men were eventually arrested and charged with vandalism. When interviewed, one of them looked back on the six months he spent in prison as a "happy time". He felt proud to have defended his land and he received a hero's welcome in the village when he was released. An interview with his wife, however, showed the downside of these 'heroic actions'. In the interview, she mainly emphasises pride in her husband, because he fought for the rights of the people and the next generation. She says that she always attended the court hearings and she was neither afraid nor sad when her husband went to prison. She felt support from the other palm oil opponents in the village and some local students who collected money and food for her. However, she also says she was constantly pressured by palm oil supporters who gossiped about her husband being in prison. Ibu Nur, a woman from a neighbouring village, shares a similar story. Her husband was questioned by police after the demonstration, because he was accused of carrying a weapon. Ibu Nur was very afraid during this time. If something should ever happen again, she would not want her husband to be involved in the resistance anymore, because "she has a 
trauma". She felt that nobody supported her while her husband was at the police station. Her friend explains: "we were afraid, so we kept quiet. We were afraid we would be targeted ourselves. It was difficult to gather to discuss about palm oil."

Ibu Yani, married to an oil palm opponent, was deeply emotionally affected and stressed by intra family conflict caused by the company's operations. She recalled how her twelve year old son had been arrested and retained in jail for one year, and she believed that her relatives - who were pro-plantation development, "on the company's side", ${ }^{8}$ - had falsely accused her son of crimes, leading to his arrest. She stated that the purpose of false accusations had been to threaten fathers involved in protests. Following this traumatic experience, the woman stated that she disagreed with their husband about the need to resist plantation companies: "I previously thought we should sell our land and move. But my husband wanted to resist so I went along with it because I am married. If I were alone, I would sell my land. I had already asked [the company] about the price but then changed my mind. I feel tired, I know my husband is." Following the arrest of her son, she added "I have to remind my husband to be careful when he goes out at night...I tell my husband not to go out alone - go with at least one other person". She then stated angrily, "the company is totally evil. It has not brought any advantage to me; it ruined relationships in my family. If possible, the company should get out of the village".

When strategies of resistance are controlled by men, women may experience negative consequences such as insecurity regarding livelihoods and fear for their safety when confronted with violence. It is evident that experiences of anxiety, stress and emotional upheaval are significant impacts of oil palm plantation development, and also constitute impacts of social movements.. Women have participated actively in claimed spaces by joining demonstrations, sometimes defying cultural restrictions. While these actions may not directly change the power positions of all women, for some women the resistance against oil palm has brought opportunities to voice their opinions.

\subsection{Participation through everyday practices}

Although women are absent from formal meetings, they may play important roles in intra community and household discussions about plantation projects. In the villages we studied, information about the plantation projects spread by word of mouth via informal meetings such as farmer's group meetings, and social events like weddings and family gatherings. It is therefore crucial to look beyond the participation of women in formal meetings and organised actions such as demonstrations to understand how women experience and respond to agrarian transformations in different ways. Here we provide three examples of alternative spaces of participation: where decisions are made in more subtle and incremental, but important ways.

First, although there are social restrictions for women to engage in political discussions, it seems that the topic stimulated some women to defy cultural norms. For example, one young woman, the sister in law of a resistance leader, asserted that the gravity of the situation gave her the courage to contradict her uncle when he praised the plantation project during a family gathering. Earlier, the company placed land marks in the rubber garden of her parents without consulting them. Hence, when she overheard her uncle praising the plantation project, she argued with him:

\footnotetext{
${ }^{8}$ There are likely to be intersecting forms of marginality. In this particular account, those "on the company's side" were villagers who did not own land and had been promised benefits from the company in return for their support for plantation development. How these different individuals - members of the same family - relate to processes of plantation development can therefore reflect context-specific power structures based on social categorisations (Matsuda 1990; Kaijser and Kronsell 2013).
} 
"It was so important, that I had the courage to speak up to my uncle, even when I am not supposed to." "Uncle, did you read the appendices of the project proposal? Look, 80\% [of the land] is for the company and $20 \%$ is for the people, in accordance with applicable laws. Do you know what that means? He did not know. It means we have to surrender our land to the company. I asked my mother if she wanted to be a kuli (coolie, local term for labourer). She did not want to be a kuli. My mother is a midwife and therefore has a lot of influence, so she could spread the warning against the company. Later, at a family gathering, I overheard men discussing the matter: they said, 'we do not want to become labourers on our own lands'. I said nothing, but in my heart I rejoiced."

The woman continued, "land in this region is very arable, and there is enough land available. If you have time and labour force, you can plant many crops. Me and my husband cultivate pineapple in addition to rubber." This leads to a second important role of women: managing agricultural activities is an indirect, yet, crucial way of making decisions on plantation development that is not always recognised or valued as such. 'Making decisions' in this context does not always involve a tactical decision by an individual woman. Rather, women's labour of cultivating land can indirectly contribute to countering the notion of empty land available for plantation development.

One of the leaders of a group of palm oil opponents stressed that in order to prevent the company from taking over the village lands, the people need to cultivate as much land as possible. His farmers' group is therefore preparing uncultivated land in the degraded forest behind the village to convert it into a rubber garden. He confides that he sometimes feels that he cannot talk to his wife about politics, because she appears to not be interested. His wife on the other hand, admits that she is sometimes disappointed that her husband uses time and energy on the resistance against companies, leaving little time to assist her with planting and harvesting.

She said: "he is always on the road, going to faraway places. Our family struggles. It is heavy for me. I told him he should not go to these distant villages; he should not take care of them as well. It is dangerous; there are many people who use mystical tricks there. You might end up poisoned. Let them take care of themselves. Sometimes I feel that he should only take care of the family instead".

The husband feels that only he is interested in politics and resisting the plantation. However, as he himself stressed, a strategy to prevent companies from taking over village land is to cultivate as much as possible. If not for his wife, the rice fields and rubber gardens would not be maintained during the conflict.

Because men between the ages of 18-40 were often working in Malaysia, women are left to work in households, fields and gardens, and their actions in physically cultivating land, and reclassifying its status, can be significant. Seeing agricultural practices as a form of resistance against land acquisition must be understood in relation to the discourse often used by governments and companies to legitimate plantation development. Representing places targeted for plantation development as 'unproductive', 'empty' land, companies and government officials render preexisting land uses invisible and land users insignificant (Cramb and McCarthy, 2016; Tsing, 2005). While some women explicitly talked about cultivating land to prevent companies from taking it, cultivating land was mostly part of everyday livelihood strategies and not necessarily intended as resistance. Yet, women's collective effort to grow crops could be recognized and further organized to advocate alternative pathways of rural development rather than oil palm plantations.

A third response to plantation development through women's everyday practices could be seen in how women cope with the changes after plantations have been established. In one case 
studied, oil palm plantation development proceeded, and the vast proportion of workers was female. When asked about their working hours, female workers stated that they worked from 7 o'clock in the morning until 3 o'clock in the afternoon. When observing women at the plantation, their tasks were extremely laborious, but they generally settled for lunch at noon for one hour, and then returned home. Their early returns home were justified by the strenuous nature of their work, the low daily wages they earn, and their household responsibilities. ${ }^{9}$ Women described benefits of working on the plantation that had encroached upon village land, demonstrating that they could be at once dispossessed and benefited by the changes accompanying rural transformations. In a discussion with two female villagers, who now work doing weeding on an oil palm plantation, one (outgoing) woman stated "I'm happy with the work now. It's easier; it's easy to buy food, and other things. We both work. I don't have to ask my husband for money. I feel more independent". In a separate discussion with a single woman in the same village, stated, "At first I didn't like it, it was too hot. Now I enjoy it, I have lots of friends to talk to".

Bissonnette (2013) highlighted how (largely male) managers tend to portray female labour as "light" and as an opportunity for "socialisation". While such discourses may devalue female labour; these discourses can also be re-appropriated by women themselves. Rural transformations, and communities, are more complex than such discourse would suggest, and by examining women's experiences and responses, we can better understand how they are not just "impacted" by change but may experience and respond in unexpected ways.

\section{REFLECTIONS AND CONCLUSIONS}

By participating in women's everyday activities, we explored various spaces where women engage with processes of land acquisition for plantation development. Looking at the micro-politics of participation, our experiences revealed how spaces for participation can be simultaneously inclusive and exclusive. Heightened awareness of how spaces are gendered helped us to examine the variety of practices used by women, going beyond 'front room' spaces where their voices may be silenced or restricted. Emotional and subjective experiences are under-appreciated in accounts of rural transformations. Protests and local (male) 'heroic actions' may be occasionally romanticised in political ecological literature, with a lack of attention to how resistance movements can be exclusionary to certain people in certain contexts, at certain times. While women's voices are seemingly limited, this does not mean that women are powerless regarding oil palm development, or similar processes of agrarian change. By exploring women's agency in different spaces we dissected a more comprehensive understanding of experiences of land acquisition for plantation development and resistance, acknowledging the role of emotions such as anxiety, fear, courage, and ambivalence. Our findings illustrate that women's experiences of processes of oil palm plantation development are diverse: oil palm opponents can fear the opposition; successful opposition can disrupt social relations; dispossession and new opportunities can co-exist; women can defy socio-cultural norms. We argue that more attention to diverse and gendered responses to, and experiences of, agrarian change can contribute to a more comprehensive understanding of such processes.

In contribution to scholarship on how governance initiatives include women's voices, we have illustrated how 'front room' spaces are often (physically and symbolically) closed to women. Although women were sometimes invited, they experienced these spaces as closed. Even if women are physically present, their voices may be silenced or weakened. The lack of confidence reported by

\footnotetext{
${ }^{9}$ This is also described by Li, 2017.
} 
women to engage in these spaces reflects gender norms which cannot easily be overcome in limited periods of time. If women are excluded from entering these spaces, their interests are not represented and their positions during times of rural transformation are further undermined. In spaces where communities resist plantation development, women's political agency was equally constrained by patriarchal contexts; the spaces were also experienced as closed to women. However, we observed that in some cases women defied social norms to claim access to 'front room' spaces, creating novel opportunities for political participation by women. For governance initiatives to include women, it is important to consider where spaces are male-dominated, and to acknowledge the potential lack of representation of alternative or subordinate voices. A practical consideration for enhancing women's participation is to include women by considering, and inviting them as individuals, not as a homogenous group.

Furthermore, if studies and governance processes are restricted to examining women's participation and voice in 'front room' spaces, they neglect women's agency in alternative spaces, such as demonstrations, in household spaces, or in fields and gardens. We showed how women used both direct and indirect ways of expressing their voices to claim rights, sometimes challenging dominant social norms of how they should behave. Further ethnographic studies examining such alternative spaces could reveal ways in which women's agency could be strengthened (for example through women's farmers' groups; organizing women plantation workers). By recognising women's attempt to engage with, respond to and resist detrimental forms of agrarian change, "alternative pathways can be imagined, and bad change can become better change" (Rigg, 2017). Although this may not directly prevent or address the violent consequences of plantation development (Li, 2017), it may start to generate some preliminary ideas on how to avoid women becoming trapped in plantation life.

Contributing to previous research on gendered impacts of oil palm plantation development, we find that impacts stretch beyond livelihood opportunities, access to land and resources, and labour conditions. Plantation development also affects and changes social relations, leading to insecurity and anxiety, and new spaces for participation. Responses and experiences are ambivalent; there is not always a strict division of women being negatively impacted or benefiting from plantation development. While the structural constraints to women's participation in processes of plantation development can be disempowering, women use alternative strategies to demonstrate their agency, and thus cannot be broadly described as "disempowered". Women frequently demonstrate resilience and adaptability to changing circumstances, and while impacts of development are gendered, it is not a simple case of winning or losing. We call for more nuanced, empirical research on different ways women experience, adapt to or resist land acquisition for (oil palm) plantation development to critically assess policy interventions for gender equality. 


\section{References}

Ali, R., 2015. Rethinking representation: negotiating positionality, power and space in the field. Gender, Place \& Culture. Journal of Feminist Geography 22 (6), 783-800.

DOI: 10.1080/0966369X.2014.917278

Agarwal, B., 1997. Environmental action, gender equity and women's participation. Development and Change 28(1), 1-44. DOI:10.1111/1467-7660.00033

Agarwal, B., 2001. Participatory exclusions, community forestry, and gender: An analysis for South Asia and a conceptual framework. World Development 29(10), 1623-1648. DOI: 10.1016/S0305-750X(01)00066-3

Basnett, B.S., Gnych, S., and Anandi, C.A.M., 2016. Transforming the Roundtable on Sustainable Palm Oil for greater gender equality and women's empowerment. CIFOR infobrief. Bogor, Indonesia: Center for International Forestry Research (CIFOR). Retrieved from cifor.org/nc/online-library/browse/view-publication/publication/6383.html

Behrman, J., Meinzen-Dick, R., and Quisumbing, A., 2012. The gender implications of large-scale land deals. Journal of Peasant Studies 39(1), 49-79. DOI: 10.1080/03066150.2011.652621

Bissonnette, J.F. 2013. Development through large-scale oil palm agribusiness schemes: Representations of possibilities and the experience of limits in West Kalimantan. SOJOURN: Journal of Social Issues in Southeast Asia, 28(3), 485-511.

Bissonnette, J. F., 2012. Envisioning agribusiness: land, labour and value in a time of oil palm expansion in Indonesia. Doctoral dissertation, University of Toronto.

Borras Jr, S.M. and Franco J.C., 2014. From threat to opportunity? Problems with codes of conduct for land grabbing. Rethinking Food Systems, 147-162. Springer Netherlands.

Brown, M. F., 1996. Forum: on resisting resistance. American Anthropologist 98(4), 729-735. DOI: 10.1525/aa.1996.98.4.02a00030

Butz, D. and Besio, K., 2009. Autoethnography. Geography Compass 3 (5): 1660-1674. DOI: 10.1111/j.1749-8198.2009.00279.x

Castellanos-Navarrete, A., and Jansen, K., 2015. Oil palm expansion without enclosure: and environmental narratives. Journal of Peasant Studies 42(3-4), 791-816.

DOI:10.1080/03066150.2015.1016920

Cornwall, A., 2002. Making spaces, changing places: situating participation in development. Institute of Development Studies, working paper 170. Institute of Development Studies, University of Sussex.

Cornwall, A., 2003. Whose voices? Whose choices? Reflections on gender and participatory development. World Development, 31(8), 1325-1342. DOI: 10.1016/S0305-750X(03)00086-X

Cornwall, A., 2008. Unpacking "Participation": models, meanings and practices. Community Development Journal 43(3), 269-283. DOI: 10.1093/cdj/bsn010

DPRD Kabupaten Sambas, 2013. Laporan pelaksanaan tugas panitia angket tentang perkebunan kelapa sawit di kabupaten Sambas. (Task performance report of the research committee about oil palm plantations in Sambas district).

Elmhirst, R., 2011. Introducing new feminist political ecologies. Geoforum 42(2), 129-132. DOI: 10.1016/j.geoforum.2011.01.006

Elmhirst, R., Siscawati, M., and Basnett, B. S., 2015. Navigating investment and dispossession: gendered impacts of the oil palm 'land rush' in East Kalimantan, Indonesia. Paper presented atthe 
'Land grabbing, conflict and agrarianenvironmental transformations: perspectives from East and Southeast Asia' conference, Chiang Mai University.

Elmhirst, R. and Darmastuti, A., 2015. Material feminism and multi-local political ecologies: rethinking gender and nature in Lampung, Indonesia. In: Lund, R., Doneys, P. and Resurreccion, B.P., editors. Gendered entanglements: re-visiting gender in rapidly changing Asia. NIAS Press, Copenhagen, pp. 177-206.

Elmhirst, R., and Resurreccion, B. P., 2008. Gender, environment and natural resource management: new dimensions, new debates. In: Elmhirst, R., and Resurreccion, B. P., editors. Gender Natural Resource Management: Livelihoods, Mobility and Interventions. International Development Research Centre, London, pp. 3-22.

Esteves, A. M., Franks, D., \& Vanclay, F., 2012. Social impact assessment: the state of the art. Impact Assessment and Project Appraisal 30(1), 34-42.

Feintrenie, L., 2014. Agro-industrial plantations in Central Africa, risks and opportunities. Biodiversity and Conservation 23(6), 1577-1589.

Gaventa, J., 2004. Towards participatory governance: assessing the transformative possibilities. In Hickey, S. and Mohan, G., Editors. Participation-From Tyranny to Transformation? Exploring New Approaches to Participation in Development (pp. 25-41). Zed Books, London.

Gaventa, J., 2006. Finding the spaces for change: a power analysis. IDS Bulletin 37(6), 23-33. DOI: 10.1111/j.1759-5436.2006.tb00320.x

Gillespie, P., 2011. How Does Legislation Affect Oil Palm Smallholders in the Sanggau District of Kalimantan, Indonesia? Australasian Journal of Natural Resources Law and Policy 14(1), 1-37.

Gutmann, M.C. 1993. Rituals of resistance: a critique of the theory of everyday forms of resistance. Latin American Perspectives, 20 (2), 74-92.

Haug, M., 2017. Men, women, and environmental change in Indonesia: the gendered face of development among the Dayak Benuaq. Austrian Journal of South-East Asian Studies 10 (1), 29-46.

Hickey, S., and Mohan, G., 2004. Participation-from tyranny to transformation? Exploring new approaches to participation in development. London: Zed Books.

Hirsch, C., 2017. Makers and shapers of environmental policy making: Power and participation forest legislation in Bolivia. Journal of Rural Studies 50, 148-158.

DOI: 10.1016/j.jrurstud.2016.11.013

Holloway, L., and Hubbard, P. People and place: The extraordinary geographies of everyday life. Routledge.

Julia and White, B., 2012. Gendered experiences of dispossession: oil palm expansion in a Dayak Hibun community in West Kalimantan. Journal of Peasant Studies 39(3-4), 995-1016. DOI: 10.1080/03066150.2012.676544

Kaijser A. and Kronsell, A. 2013. Climate change through the lens of intersectionality, Environmental Politics. 23 (3), 417-433.

Kerkvliet, B. J., 2009. Everyday politics in peasant societies (and ours). Journal of Peasant Studies 36(1), 227-243. DOI: 10.1080/03066150902820487

Kesby, M., 2005. Retheorizing empowerment-through-participation as a performance in space: beyond tyranny to transformation. Signs 30(4), 2037-2065.

Kohn, M., 2000. Language, power, and persuasion: toward a critique of deliberative democracy. Constellations 7(3), 408-429. DOI: 10.1111/1467-8675.00197 
Lamb, V., Schoenberger, L., Middleton, C., \& Un, B. 2017. Gendered eviction, protest and recovery: a feminist political ecology engagement with land grabbing in rural Cambodia.

The Journal of Peasant Studies, 44(6), 1215-1234.

Lawrence, A., 2006. "No Personal Motive?" volunteers, biodiversity, and the false dichotomies of participation. Ethics, Place \& Environment 9(3), 279-298. DOI:10.1080/13668790600893319

Leach, M., 2007. Earth mother myths and other ecofeminist fables: How a strategic notion rose and fell. Development and Change 38(1), 67-85. DOI: 10.1111/j.1467-7660.2007.00403.x

Leal, P. A. 2007. Participation: the ascendancy of a buzzword in the neo-liberal era. Development in Practice, 17(4-5), 539-548. DOI: 10.1080/09614520701469518

Lefebvre, H., 1991. The Production of Space (Vol. 142) (translated by Nicholson-Smith, D.), Blackwell, Oxford.

Li, T.M., 2015. Social impacts of oil palm in Indonesia: a gendered perspective from West Kalimantan. Occasional paper 124. CIFOR, Bogor.

Li, T.M., 2017. After the land grab: Infrastructural violence and the "Mafia System" in Indonesia's oil palm plantation zones. Geoforum, http://dx.doi.org/10.1016/j.geoforum.2017.10.012

Lykke, N. (2010) Feminist studies. A guide to intersectional theory, methodology and writing. New York: Routledge.

McCarthy, J.F., and Cramb, R.A., 2009. Policy narratives, landholder engagement, and oil palm expansion on the Malaysian and Indonesian frontiers. Geographical Journal, 175(2), 112-123.

McCarthy, J.F., 2010. Processes of inclusion and adverse incorporation: oil palm and agrarian change in Sumatra, Indonesia. Journal of Peasant Studies 37(4): 821-850.

DOI: $10.1080 / 03066150.2010 .512460$

Matsuda, M. 1990. Beside my sister, facing the enemy: legal theory out of coalition. Stanford Law Review, Vol. 43: 1183-1192

Mee, W., 2015. Work and cosmopolitanism at the border: Indonesian women labour migrants. Journal of Ethnic and Migration Studies 41(12), 2041-2060.

DOI: 10.1080/1369183X.2015.1049589

Morgan, M., 2017: Women, gender and protest: contesting oil palm plantation expansion in Indonesia. Journal of Peasant Studies. DOI: 10.1080/03066150.2017.1300579

Muhammad, M., Wallerstein, N., Sussman, A. L., Avila, M., Belone, L., and Duran, B., 2015. Reflections on researcher identity and power: the impact of positionality on community based participatory research (CBPR) processes and outcomes. Critical Sociology 41(7-8), 1045-1063.

Nelson, B. V. and Lambrou, Y., 2011. Scoping the Gender Issues in Liquid Biofuel Value Chains.

NRI Working Paper Series: Climate Change, Agriculture and Natural Resources No. 3.

University of Greenwich, UK. Climate change, agriculture and natural resources scoping the gender Issues in liquid biofuel value chains (3).

Nightingale, A. J. 2002. Participating or just sitting in? The dynamics of gender and caste in community forestry. Journal of forest and livelihood vol, 2(1).

Nightingale, A. J. 2011. Bounding difference: Intersectionality and the material production of gender, caste, class and environment in Nepal. Geoforum, 42(2), 153-162. 
O'Shaughnessy, S., and Krogman, N. T., 2011. Gender as contradiction: From dichotomies to diversity in natural resource extraction. Journal of Rural Studies, 27(2), 134-143.

DOI: 10.1016/j.jrurstud.2011.01.001

Potter, L., 2008. Dayak resistance to oil palm plantations in West Kalimantan, Indonesia.

Paper presented at the 17th biennial conference of the Asian studies association of Australia, Melbourne (1-3).

Rigg, J., 2017. Possibilities for redemption and alternatives in Tania Li's Indonesian plantation 'Mafia System'. Geoforum, DOI: 10.1016/j.geoforum.2017.11.013.

Scott, J. C., 1985. Weapons of the Weak: Everyday Forms of Peasant Resistance. Yale University press, New Haven.

Scott, J. C., 1990. Domination and the Arts of Resistance: Hidden Transcripts. Yale University press, New Haven.

Soja, E., 1996. The Third Space: Journeys to LA and other Real-and-imaginated Places. Blackwell, Oxford.

Sultana, F., 2007. Reflexivity, positionality and participatory ethics: negotiating fieldwork dilemmas in international research. ACME: An international Journal for Critical Geographies 6(3), 374-385.

Sultana, F. 2011. Suffering for water, suffering from water: emotional geographies of resource access, control and conflict. Geoforum, 42(2), 163-172.

DOI:10.1016/j.geoforum.2010.12.002

Tallontire, A., Opondo, M., and Nelson, V., 2014. Contingent spaces for smallholder participation in GlobalGAP: insights from Kenyan horticulture value chains. Geographical Journal 180(4), 353-364. DOI: 10.1111/geoj.12047

Tandon, Y., 1995. Poverty, processes of impoverishment and empowerment: a review of current thinking and action. In: Singh, N. and Titi, V., Editors. Empowerment: Towards Sustainable Development. Zed Books, London: pp. 29-36. 